\title{
Economic viability of LFG recovery under the CDM mechanism
}

\author{
L. Abi-Esber \& M. El-Fadel \\ Department of Civil and Environmental Engineering, \\ American University of Beirut, Lebanon
}

\begin{abstract}
This paper examines the viability of investment in landfill gas (LFG) recovery and power generation under the clean development mechanism (CDM). The analysis is conducted at a prototype closed landfill with 4 million tons of organic waste and a $\mathrm{CH}_{4}$ generation potential of 19.8 to $102.6 \mathrm{~m}^{3} /$ ton of waste estimated on the basis of field measurements. Five power generation technologies were compared including reciprocating internal combustion engines, gas turbines, organic Rankine cycle engines, Stirling cycle engines, molten carbonate fuel cells and solid oxide fuel cells at a capacity of 0.5 or $1 \mathrm{MW}$. None of the tested technologies exhibited favorable economic viability at the measured LFG emission rates. Using larger emission rates, certain schemes could pay back within a period of 7 years depending on the size of the generator and the cost of the power generation technology. Therefore, CDM initiatives are not always viable particularly in developing countries with waste streams characterized with high organic fraction. They need to be based on careful examination of waste characteristics and landfill history which are closely correlated with the magnitude and trend of LFG emissions.
\end{abstract}

Keywords: landfill gas, energy recovery, power generation, clean development mechanism, developing countries.

\section{Introduction}

Solid waste is considered a source of greenhouse gas (GHG) emissions due to microbial decomposition of organic materials. The latter constitute the greater portion of solid waste in developing countries where landfills remain an essential element of any waste management system and often the only economic form of 
waste disposal. In the absence of oxygen (anaerobic conditions), the decomposition process produces primarily methane $\left(\mathrm{CH}_{4}\right)$ and carbon dioxide $\left(\mathrm{CO}_{2}\right)$ with $\mathrm{CH}_{4}$ having received greater attention as a significant contributor to global warming. Together with $\mathrm{CH}_{4}$ emissions from fossil fuel, landfill $\mathrm{CH}_{4}$ emissions are reported to be the most practical ones to mitigate in order to stabilize $\mathrm{CH}_{4}$ concentration in the atmosphere (De Visscher et al. [1]).

The Kyoto Protocol offers countries facing emission targets the possibility of purchasing certified emission reduction (CER) credits from developing countries (referred to as Non-Annex B parties) under the clean development mechanism (CDM) initiative (Larson et al. [2]). Since the location of emissions does not matter from a global warming perspective, the achievement of reduction targets depends in large part upon the ability of Annex B countries to substitute cheaper emission reductions in non-Annex $B$ regions for equivalent abatement at home (Ellerman et al. [3]). In this context, LFG and waste management projects were a primary CDM target and gained 11\% of the CDM market share in 2009 (Kossoy and Ambrosi [4]). However, reviews of project reports for the same period (Ballik [5]; Peterson et al. [6]; Unnikrishnan and Singh [7]) revealed that LFG projects have failed to deliver the targeted emission reductions. The leading cause for this shortfall is over-expectation due to the lack of accurate quantification of LFG emissions in the developing world and the subsequent use of high rates of LFG generation.

According to Greiner [8], the ideal approach to distinguish between commercially attractive CDM projects and those which can benefit from smallscale procedures is the definition of a threshold size of the landfill. Below this threshold, investments' feasibility depends on the ability of the developer to accurately estimate landfill emissions, with the magnitude of emissions being closely related to waste quantity and composition (El-Fadel et al. [9]).

In this study, a landfill with 4 million tons of organic waste was considered to assess its suitability as a candidate CDM project thus providing a prototype evaluation approach for landfills in developing countries with similar waste characteristics. For this purpose, the energy recoverable from LFG emissions was estimated for a seven-year period following its closure based on field measurements and mathematical simulations. An economic analysis was then conducted to test the feasibility of implementing small scale LFG recovery and power generation schemes at the site, and to define a threshold size above which a CDM project becomes feasible in similar contexts.

\section{Materials and methods}

\subsection{Site description}

The site consists of a non-engineered landfill with a footprint area of 20 hectares located along the Eastern Mediterranean shoreline in the city of Beirut, Lebanon (Figure 1). The site is reported to have experienced waste disposal activities from 1975 till 1997 at varying rates (Table 1) with high food waste fraction (Table 2). Control measures implemented at the site have been limited to the deployment of a soil cover along with drilling of several penetrating gas vents. 
Table 1: Waste stream quantities deposited at the site.

\begin{tabular}{ccc}
\hline Year & $\begin{array}{c}\text { Annual Waste Flow } \\
\text { (tons/yr) }\end{array}$ & $\begin{array}{c}\text { Daily Waste Flow } \\
\text { (tons/day) }\end{array}$ \\
\hline 1975 to 1989 & 100,000 & 274 \\
1990 & 219,000 & 800 \\
1991 & 260,063 & 950 \\
1992 & 301,125 & 1,100 \\
1993 & 328,500 & 1,200 \\
1994 & 355,875 & 1,300 \\
1995 & 383,250 & 1,400 \\
1996 & 410,625 & 1,500 \\
1997 & 438,000 & 1,600 \\
Total (tons) & $4,196,438$ & - \\
\hline
\end{tabular}

Source: SWECO International [11].

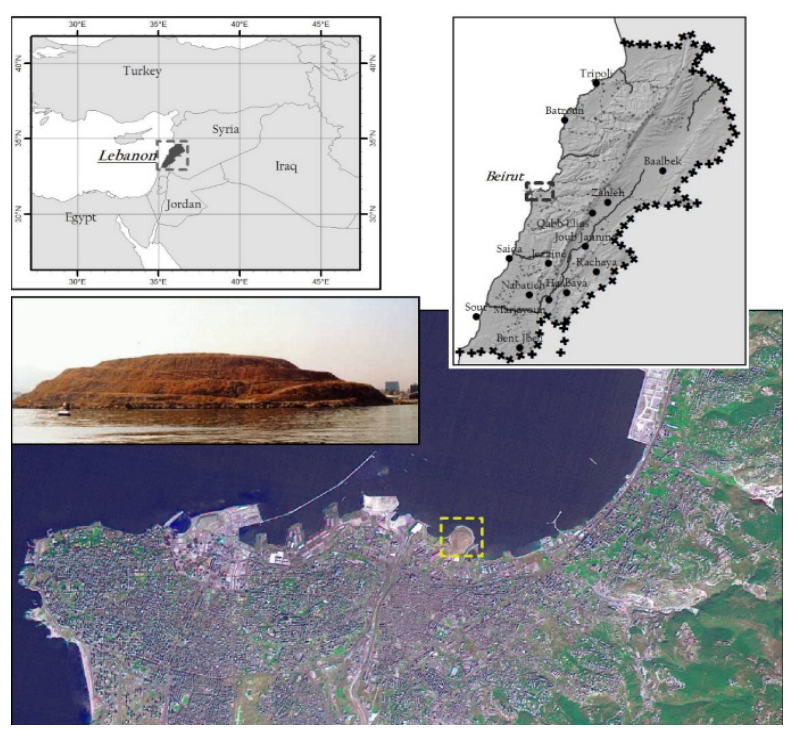

Figure 1: General site location.

LFG emissions at the site were measured in the year 2001 (four years after its closure) at 40 headspace locations and 4 onsite boreholes (gas vents) during four consecutive weeks (El-Fadel et al. [9]). A $\mathrm{CH}_{4}$ flux of 0.000 to $3.644 \mathrm{l} / \mathrm{m}^{2} . \mathrm{hr}$ was reported with an arithmetic mean of $0.240 \pm 0.7081 / \mathrm{m}^{2} . \mathrm{hr}$. Using field measurements, the Scholl-Canyon model was calibrated to simulate LFG emissions at the site for the years 1997-2018 (Figure 2). The simulation trends indicated a sharply decreasing level of LFG emissions and a $\mathrm{CH}_{4}$ generation 
86 Waste Management and the Environment VI

Table 2: Waste composition.

\begin{tabular}{cc}
\hline Waste Components & $\begin{array}{c}\text { Average Composition \% by wet } \\
\text { weight }\end{array}$ \\
\hline Food waste & 52 \\
Paper & 6 \\
Cardboard & 7 \\
Wood & 1 \\
Textiles & 4 \\
Plastics & 23 \\
Glass & 1 \\
Metals & 2 \\
Dirt & 4 \\
\hline
\end{tabular}

Source: El-Fadel et al. [9]

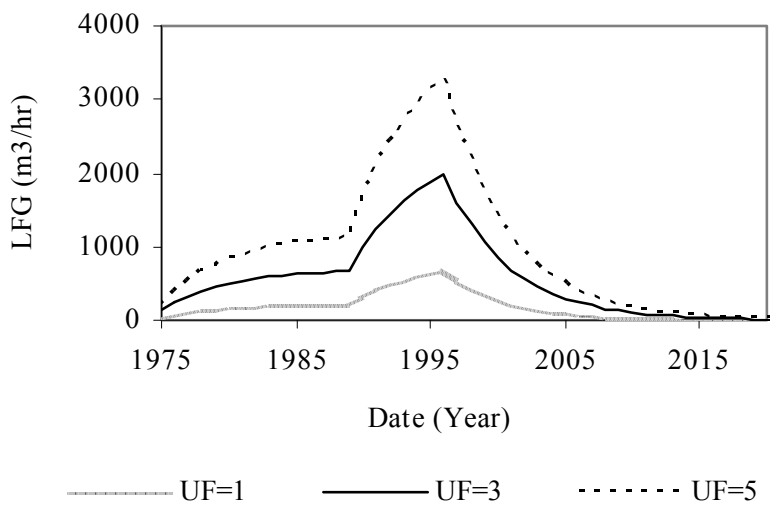

Figure 2: $\quad$ Simulated LFG emissions.

potential of 19.8 to $102.6 \mathrm{~m}^{3} /$ ton of waste (El-Fadel et al. [9]. Uncertainty factors (UF) of 3 and 5 were introduced to simulate the case whereby actual LFG production is respectively three and five times higher than that measured in the field due to potential errors in the applied chamber measurement technique. Indeed, chamber measurements are reported to underestimate the LFG flux by a factor of 4.2 (Börjesson et al. [10]). The use of UFs greater than one also enables the simulation of larger landfill sites with similar waste characteristics.

\subsection{Assessment of recoverable energy}

Based on model simulations and field measurements, the amount of recoverable energy was calculated for the period 1997-2004 which is the period of significant LFG production following landfill closure. For this purpose, it was assumed that the $\mathrm{CH}_{4}$ fraction in the LFG is $50.7 \%$, the capture efficiency is $50 \%$ (Peterson 
et al. [6]) and the calorific value for $\mathrm{CH}_{4}$ is $37000 \mathrm{~kJ} / \mathrm{m}^{3}$ (Couth et al. [12]). A conversion factor of 3.6 GJ per MWh of electricity was used (UNFCCC [13]).

\subsection{Energy recovery schemes}

The findings from recoverable energy calculations were used to test the economic viability of installing a LFG extraction, power generation and flaring system following landfill closure. Two scenarios were considered 1) the installation of one $0.5 \mathrm{MW}$ generator and flaring of excess LFG as needed, and 2) the installation of two $0.5 \mathrm{MW}$ generators and flaring of excess LFG as needed. Five power generation technologies were compared including reciprocating internal combustion engines (ICE), gas turbines (GT), organic Rankine cycle engines (ORC), molten carbonate fuel cells (MCFC) and solid oxide fuel cells (SOFC). These technologies were selected because they are available of relatively small size systems and they can be fueled by LFG (Bove and Lunghi [14]).

ICEs represent the most employed technology for electric generation due to the associated low investment cost. They constitute a consolidated technology with low economic risks compared to other technologies. Moreover, they are compact and easy to transport between wells if needed. GTs constitute the second most used technology of LFG energy conversion and are associated with more losses and lower performance than ICEs particularly when running at reduced load. ORCs are based on the same thermodynamic cycle as the classical traditional Rankine (used for steam turbine power plants), with the exception of the working fluid which is typically iso-butane or propane rather than water. ORCs can be designed to be modular thus allowing the realization of power modules in the range of a few MWs. MCFCs and SOFCs offer the advantage of operation with higher impurities' gases due to the high operation temperature $\left(650\right.$ to $\left.1000^{\circ} \mathrm{C}\right)$. They are also modular, and are reported to be associated with considerable pollution reduction but at high investment and as such they still cannot be considered as a fully demonstrated technology. The characteristics of the proposed systems are outlined in Table 3.

\subsection{Economic analysis}

The crediting period for a CDM project activity is selected by the project proponent, and may be either a 7-year crediting period renewable twice or a single 10-year crediting period. In the current work, a 7-year crediting period is assumed due to the large drop in LFG generation beyond the year 2004 . Assuming that it takes one year to install the system, operation and maintenance costs are applied at the start of the second year and are proportional to the number of operating generators. Total recoverable CER units are calculated based on captured $\mathrm{CH}_{4}$ used for power generation or flared, and on offset emissions from avoided combustion of fossil fuels. For the latter, a value of 0.8 $\mathrm{tCO}_{2} / \mathrm{MWh}$ and a global warming potential of $21 \mathrm{tCO}_{2} / \mathrm{tCH}_{4}$ were adopted (UNFCCC [13]). Engines' electrical efficiencies (Table 3) and flare efficiency 
Table 3: Techno-economic values relative to extraction, power generation and flaring systems.

\begin{tabular}{|c|c|c|c|c|}
\hline & $\begin{array}{c}\text { Electrical } \\
\text { efficiency } \\
(\%)\end{array}$ & $\begin{array}{c}\text { Investment cost } \\
\text { (Million } \\
\text { USD/MW) }\end{array}$ & $\begin{array}{c}\text { Operation and } \\
\text { maintenance } \\
\text { (USD/kW/year) }\end{array}$ & $\begin{array}{c}\text { Emissions } \\
(\mu \mathrm{g} / \mathrm{kJ})\end{array}$ \\
\hline $\mathrm{ICE}^{\mathrm{a} /}$ & 33 & 1.2 & 115.2 & $\begin{array}{c}\mathrm{NO}_{\mathrm{x}}: 56.6 \\
\text { CO: }: 56.6\end{array}$ \\
\hline $\mathrm{GT}^{\mathrm{a} /}$ & 28 & 1.5 & 99.84 & $\begin{array}{c}\mathrm{NO}_{\mathrm{x}}: 15 \\
\mathrm{CO}: 19\end{array}$ \\
\hline $\mathrm{ORC}^{\mathrm{a} /}$ & 18 & 1.5 & 61.44 & $\begin{array}{c}\mathrm{NO}_{\mathrm{x}}: 16 \\
\mathrm{CO}: 18.9\end{array}$ \\
\hline $\mathrm{MCFC}^{\mathrm{a} /}$ & 50 & 2.8 & 96 & $\begin{array}{c}\mathrm{NO}_{\mathrm{x}}: \text { Trace } \\
\mathrm{CO}: 1.4\end{array}$ \\
\hline $\mathrm{SOFC}^{\mathrm{a} /}$ & 50 & 3.5 & 84 & $\begin{array}{c}\mathrm{NO}_{\mathrm{x}}: \text { Trace } \\
\mathrm{CO}: 1.4\end{array}$ \\
\hline $\begin{array}{l}\mathrm{Gas} \mathrm{extraction}^{2} \text { and } \\
1000 \mathrm{Nm}^{3} / \mathrm{h} \text { flare }\end{array}$ & - & 1 & - & - \\
\hline
\end{tabular}

a/ Source: Bove and Lunghi [14]; b/ Source: Couth et al. [12].

(90\%) were accounted for in the calculations. A discount rate of $4 \%$ is applied to compute the present value of the annual costs of installing and running the LFG extraction, power generation and flaring systems for 7 years. The same discount rate was applied to calculate the present value of the annual benefits from selling the generated electricity at a price of $9.4 \mathrm{US}$ cents/kwh (Dagher and Ruble [15]) and the generated CERs at a price of $16.3 \mathrm{USD} / \mathrm{tCO}_{2}$ (Couth et al. [12]). A yearly cumulative balance of profits was computed afterwards to assess the project's payback time (PBT), which is the year of the investment in which the net present value of the cumulative balance of profits equals zero.

\section{Results and discussion}

\subsection{Assessment of recoverable energy}

Findings from recoverable energy calculations (Figure 3) indicate a sharply decreasing trend immediately after landfill closure due to the cessation of waste flow into the site and to the high biodegradability of food waste. The potential of power recovery ranged from 0.27 to $1.19 \mathrm{MW}$ for the years 1997-2004 with $\mathrm{UF}=1$. For UFs of 3 and 5 , the power content is evidently higher with respective peaks of 3.58 and $5.97 \mathrm{MW}$ at landfill closure. The power content drops sharply afterwards to reach respective levels of 0.82 and $1.37 \mathrm{MW}$ in the year 2004, and 0.15 and $0.26 \mathrm{MW}$ in the year 2012 . 


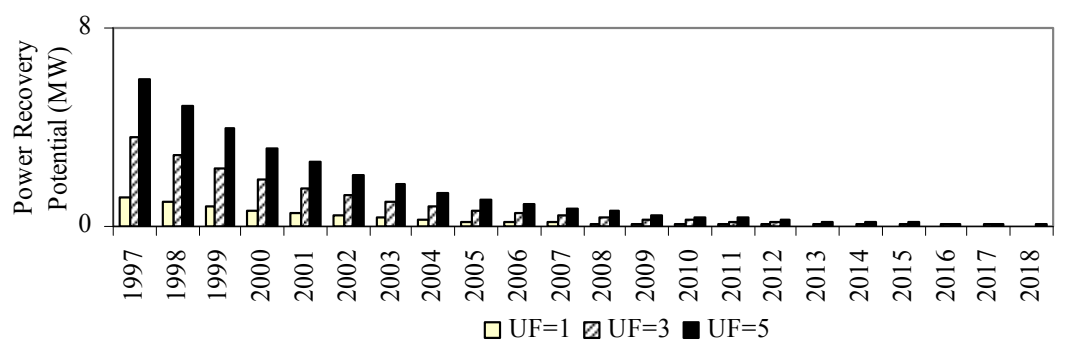

Figure 3: Simulated recoverable electric power for a 21-year period (1997-2018).

\subsection{Economic analysis}

The economic analysis results are depicted in Figure 4. Figures $4 \mathrm{a}$ and $4 \mathrm{~b}$ show that under the field measured conditions of LFG generation, investments in power generation capacities of as low as 0.5 and $1 \mathrm{MW}$ at the time of landfill closure would not pay-back after a 7-year crediting period. If LFG generation was three times higher than that measured in the field (Figures $4 \mathrm{c}$ and $4 \mathrm{~d}$ ), all 0.5 MW power generation schemes would pay back within the 7-year crediting period (Figure 4c) with highest economic returns achievable with an ICE, followed by GT, MCFC, ORC and SOFC in decreasing order of profit. The PBT was 4 years for an ICE, 5 years for GT, ORC and MCFC and 6 years for an SOFC. Installing $1 \mathrm{MW}$ generators (Figure 4d) would pay back after 5 years with an ICE, 6 years with a GT, 7 years with an MCFC whereas ORC and SOFC systems are not economically viable.

If $L F G$ generation is five times higher than that measured in the field ( $U F=5$, Figures $4 \mathrm{e}$ and $4 \mathrm{f}$ ), the PBT for a $0.5 \mathrm{MW}$ power generation system is 2 years for an ICE, 3 years for GT, ORC and MCFC and 4 years for an SOFC, whereas the PBT for a $1 \mathrm{MW}$ power generation system is 3 years with an ICE, 4 years with a GT, ORC and MCFC, and 5 years with an SOFC.

The UF that would balance the costs and benefits at the end of the seventh year for the least expensive system (ICE) was 1.3 and 1.5 with 0.5 and $1 \mathrm{MW}$ power recovery systems, respectively. Evidently, the generation of profits requires the use of even larger UFs. Therefore, under similar cases of waste quantity and characteristics, energy recovery from LFG is not an attractive investment even if small scale recovery systems are used. Larger quantities of LFG are required to ensure project feasibility, which is equivalent to larger landfill sites and/or well-engineered and operated landfills facilitating high LFG capture rates.

Of particular importance are the findings related to the use of the MCFC technology which despite its high capital cost could generate higher profits than GTs, ORCs and SOFCs due to its high electrical efficiency. Moreover, compared to ICEs which are associated with the highest profits among all technologies, MCFCs have much lower $\mathrm{NO}_{\mathrm{x}}$ and $\mathrm{CO}$ emissions thus a significantly superior environmental performance. 

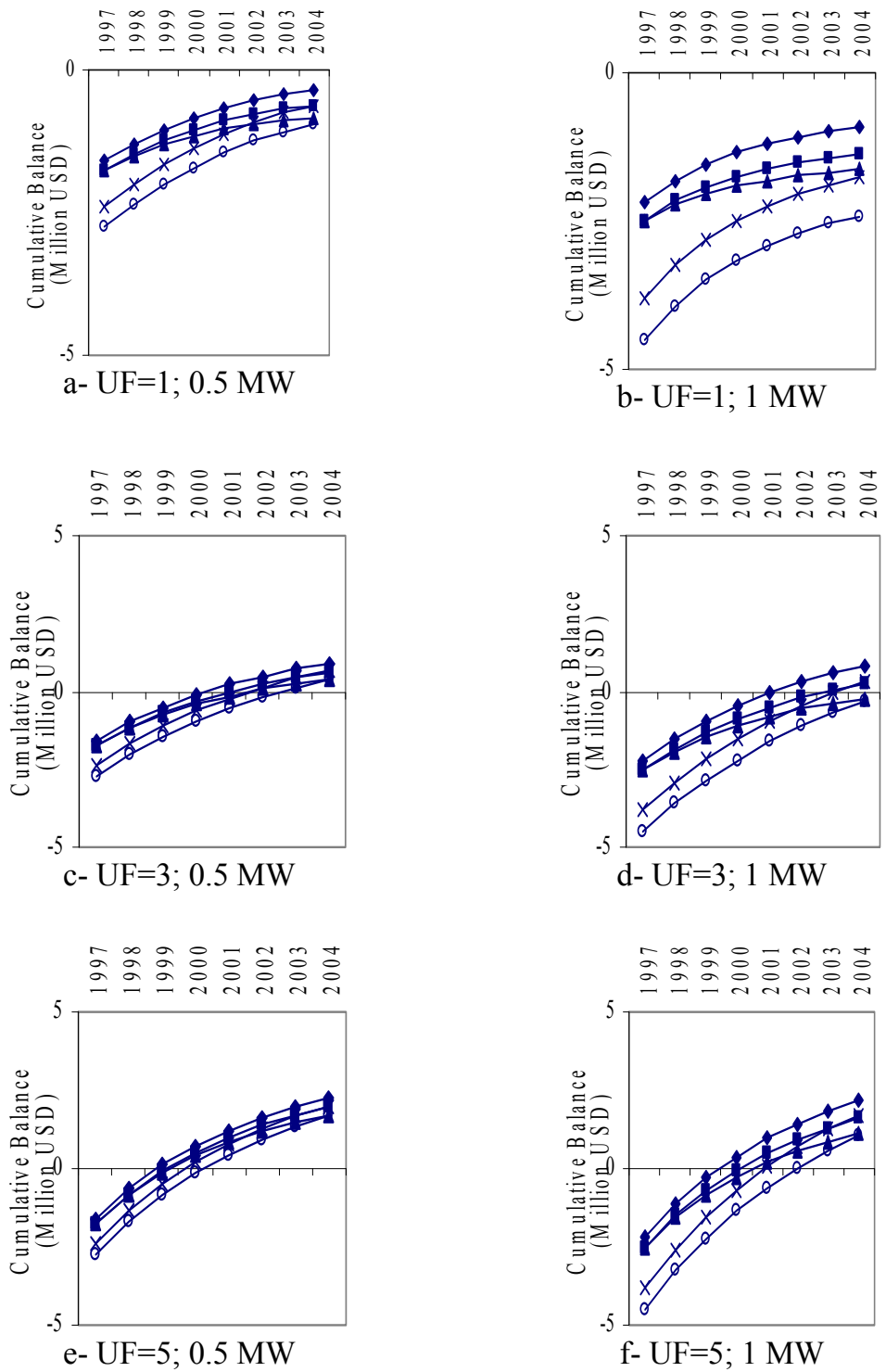

$\multimap \mathrm{ICE} \rightarrow-\mathrm{GT} \multimap \mathrm{ORC} \multimap \mathrm{MCFC} \multimap \mathrm{SOFC}$

Figure 4: Cumulative balance of profits for the period 1997-2004 following LFG extraction and partial flaring and power recovery. 


\section{Conclusion}

In this paper, the economic viability of several LFG recovery and power generation schemes was examined at a typical closed landfill site of the developing world accommodating municipal waste with high organic fraction. Tested schemes included ICEs, GTs, ORCs, MCFCs and SOFCs at a capacity of 0.5 or $1 \mathrm{MW}$. Based on actual field measurements and simulation results, the amount of recoverable energy was found to peak at $1.19 \mathrm{MW}$ immediately after landfill closure and to decrease sharply to $0.27 \mathrm{MW}$ after 7 years. At these rates, none of the tested schemes was economically viable. LFG emissions and/or landfill size should be at least 1.3 and 1.5 times larger to apply 0.5 and $1 \mathrm{MW}$ schemes, respectively, all while getting a balance of costs and benefits at the end of the seventh year. These findings raise into doubt the feasibility of investment in LFG recovery and power generation in similar contexts, and demonstrate the importance of waste characteristics and landfill history in the estimation of LFG emission trends and associated investment opportunities.

\section{References}

[1] De Visscher, A., Thomas, D., Boeckx, P., Van Cleemput, O, Methane oxidation in simulated landfill cover soil environments. Environmental Science and Technology, 33, pp. 1854-1859, 1999.

[2] Larson, D.F., Ambrosi, P., Dinar, A., Rahman, S.M., Entler, R., Carbon markets, institutions, policies and research. Policy research working paper 4761, The World Bank, Development Research Group, Sustainable Rural and Urban Development Team, 2008.

[3] Ellerman, A.D., Jacoby, H.D., Decaux, A., The effects on developing countries of the Kyoto Protocol and $\mathrm{CO}_{2}$ emissions trading. The World Bank, Joint Program on the Science and Policy of Global Change, Massachusetts Institute of Technology, 2009.

[4] Kossoy, A., Ambrosi, P, State and trends of the carbon market 2010. The World Bank, Environment Department, Carbon Finance, Washington, DC, 2010.

[5] Ballik, I., CDM landfill gas projects - A piece of cake? Retrospective on four years of $L F G$ project implementation in the carbon market. CDM Investment Newsletter Nr. 1/2008, A joint initiative of BEA International and the Climate Business Network, Carbon Finance Unit, World Bank, 2009.

[6] Peterson, C., Bowden, W.N., Bhaskar, A., Landfill gas recovery system performance. CDM Investment Newsletter Nr. 1/2008, A joint initiative of BEA International and the Climate Business Network, Carbon Finance Unit, World Bank, 2009.

[7] Unnikrishnan, and Singh, A., Energy recovery in solid waste management through CDM in India and other countries. Resources, Conservation and Recycling, 54, pp. 630-640, 2010. 
[8] Greiner, S., How to define small-scale landfill gas projects? Discussion paper, World Bank, Carbon Finance Business Unit, 2004.

[9] El-Fadel, M., Abi-Esber, L., Salhab, S., Emission assessment at the Burj Hammoud inactive municipal landfill: Viability of landfill gas recovery under the clean development mechanism. Waste Management, in press, 2012.

[10] Börjesson, G., Danielsson, Å., Svensson, B.H., Methane Fluxes from a Swedish Landfill Determined by Geostatistical Treatment of Static Chamber Measurements. Environmental Science and Technology, 34, pp. 4044-4050, 2000.

[11] SWECO International, Feasibility Study for Gas Extraction and Rehabilitation of Borj hammoud Landfill. Council for Development and Reconstruction, SWECO International AB, Envirotech Ltd, 2000.

[12] Couth, R., Trois, C., Parkin, J., Strachan, L.J., Gilder, A., Wright, M., Delivery and viability of landfill gas CDM projects in Africa - A South African experience. Renewable and Sustainable Energy Reviews, 15, pp. 392-403, 2011.

[13] United Nations Framework Convention on Climate Change (UNFCCC), Consolidated baseline and monitoring methodology for landfill gas project activities. Approved consolidated baseline methodology ACM0001, version 11, CDM Executive Board, 2009.

[14] Bove, R., Lunghi, P., Electric power generation from landfill gas using traditional and innovative technologies. Energy Conversion and Management, 47, pp. 1391-1401, 2006.

[15] Dagher, L., Ruble, I., Modeling Lebanon's electricity sector: alternative scenarios and their implications. Energy, 36, pp. 4315-4326, 2011. 